\title{
Endoparasites in group of wild animals raised in captivity $^{1}$
}

\author{
Aline Mewius², Elis Regina Lusa ${ }^{2}$, Julia G. Pertille ${ }^{2}$, Tiago D. Dos Reis ${ }^{3}$, \\ Juliana A. Pletsch ${ }^{4}$, Raqueli T. França ${ }^{5}$ (D) and Luciana L. Dias de Castro ${ }^{4 *}$ (D)
}

\begin{abstract}
Mewius A., Lusa E.R., Pertille J.G., Dos Reis T.D., Pletsch J.A., França R.T. \& Dias de Castro L.L. 2021. Endoparasites in group of wild animals raised in captivity. Pesquisa Veterinária Brasileira 41:e06758, 2021. Universidade de Caxias do Sul, Rua Francisco Getúlio Vargas 1130, Bairro Petrópolis, Caxias do Sul, RS 95070560, Brazil. E-mail: lu.ldcastro@gmail.com

Free-living wild animals can host a wide variety of endoparasites. When subjected to conditions of captivity, these animals can go through stressful situations and develop parasites. Therefore, the objective of this study was to identify parasitic infection in wild mammals, birds, and reptiles kept at the "Universidade de Caxias do Sul" Zoo, in Rio Grande do Sul state, Brazil. The population studied was based on 76 animals, divided into 50\% $(38 / 76)$ birds, 35.53\% (27/76) mammals, and 14.47\% (11/76) reptiles distributed in 33 different enclosures. Fecal samples were collected from the enclosures and analyzed in triplicate, using the centrifugal-flotation method with a zinc sulfate solution. Samples from the enclosures 31, 32, 33, (where snakes are located), and 15 (animal death), were not analyzed in triplicate, so the total number of analyses was 91 samples. The results showed that $41.76 \%(38 / 91)$ of the samples were positive for at least one class of endoparasites, such as Nematoda, Cestoda, or Coccidia. The positive samples showed the presence of at least one or more parasites from orders Strongylida (34.21\%), Enoplida and Strongylida (23.68\%), Enoplida only (23.68\%), Cyclophyllidea and Oxyurida (5.26\%), Ascaridida only (5.26\%), Enoplida, Strongylida, and Ascaridida (5.26\%), and Enoplida and Eucoccidiorida $(2.63 \%)$. Considering the positive samples, $55.26 \%$ were collected from birds, $39.47 \%$ from mammals, and $5.27 \%$ from reptiles. Capillaria sp. eggs were the main structure found in birds, and eggs from the order Strongylida were the most found in samples from mammals. This study showed the order Strongylida as the most frequent parasite found in $63.16 \%$ of the total samples, established either in isolated or mixed infestations. Also, mammals and birds were those with a greater quantity of positive samples for endoparasites. Therefore, this study emphasizes the importance of carrying out research assessing the gastrointestinal parasitic fauna in wild animals, so one can determine the conditions under which these parasites become pathogenic to wild animals raised in captivity.
\end{abstract}

INDEX TERMS: Birds, mammals, reptiles, wild animals, zoo, captivity, endoparasites, parasitic analysis.

\footnotetext{
${ }^{1}$ Received on April 20, 2021.

Accepted for publication on May 24, 2021.

${ }^{2}$ Veterinary Medicine Students, Universidade de Caxias de Sul (UCS), Rua Francisco Getúlio Vargas 1130, Bairro Petrópolis, Caxias do Sul, RS 95070560, Brazil.

${ }^{3}$ Zoo Employe and Biology Student, Universidade de Caxias do Sul (UCS), Rua Francisco Getúlio Vargas 1130, Bairro Petrópolis, Caxias do Sul, RS 95070560, Brazil.

${ }^{4}$ Faculty members, Escola de Medicina Veterinária, Universidade de Caxias do Sul (UCS), Rua Francisco Getúlio Vargas 1130, Bairro Petrópolis, Caxias do Sul, RS 95070560, Brazil. *Corresponding author: lu.ldcastro@gmail.com

${ }^{5}$ Faculty member, Faculdade de Veterinária, Universidade Federal de Pelotas (UFPel), Av. Eliseu Maciel s/n, Capão do Leão, RS 96160000, Brazil.
}

RESUMO.- [Endoparasitas em plantel de animais silvestres criados em cativeiro.] Os animais silvestres de vida livre podem albergar uma grande variedade de endoparasitas. Esses animais, quando submetidos a condições de cativeiro podem passar por situações de estresse e desenvolver parasitoses. Neste sentido, o objetivo deste trabalho foi identificar a infecção parasitária em mamíferos, aves e répteis silvestres mantidos no Zoológico da Universidade de Caxias do Sul, no Rio Grande do Sul/Brasil. A população estudada foi de 76 animais, nos quais 50\% (38/76) eram aves, 35,53\% (27/76) mamíferos e $14,47 \%$ (11/76) répteis, distribuídos em 33 recintos diferentes. 
Amostras de fezes foram coletadas dos recintos e analisadas em triplicata pelo método de centrífugo-flutuação com solução de Sulfato de Zinco. Como não foi possível analisar em triplicata o material dos recintos 31, 32, 33 os quais alojam as serpentes e o recinto 15 pois o animal veio a óbito, o total de análises foi de 91 amostras. Os resultados demonstraram que 41,76\% (38/91) das amostras foram positivas para, pelo menos, um endoparasita da classe Nematoda, Cestoda ou Coccidia. As amostras positivas indicaram a presença de um ou mais parasitas sendo da ordem Strongylida (34,21\%), Enoplida e Strongylida (23,68\%), apenas Enoplida (23,68\%), Cyclophyllidea e Oxyurida (5,26\%), apenas Ascaridida (5,26\%), Enoplida, Strongylida e Ascaridida (5,26\%), e Enoplida e Eucoccidiorida $(2,63 \%)$. Das amostras positivas $55,26 \%$ foram de aves, sendo que ovos de Capillaria sp. foi a principal estrutura identificada, $39,47 \%$ de mamíferos apontando que a ordem Strongylida foi a mais prevalente e $5,27 \%$ de répteis. 0 estudo demonstrou que, dentre os parasitas encontrados, aqueles da ordem Strongylida foram os mais frequentes, sendo observada em monoinfecção ou infecção mista em 63,16\% das amostras analisadas. Dos animais avaliados, as aves e mamíferos foram os que apresentaram maior quantidade de amostras positivas para endoparasitas. Diante disso, é importante a realização de pesquisas que permitem avaliar a fauna parasitária para que seja possível determinar as condições em que esses parasitas se tornam patogênicos aos animais cativos.

TERMOS DE INDEXAÇÃO: Aves, mamíferos, répteis, animais silvestres, zoológico, cativeiro, endoparasitas, análises parasitárias.

\section{INTRODUCTION}

Free-living, wild animals host a wide variety of parasites. Due to this parasitic diversity, eating habits, species peculiarities, and handling of enclosures in animals kept in captivity are affected. Intestinal parasitic infections are usually asymptomatic; however, young animals may be susceptible to severe parasitic infestations, which may cause critical clinical symptoms (Birchard \& Sherding 1998). The parasitosis emerges in captive animals due to stressful factors affecting their immune system, such as the presence of native rodents or wild birds, contributing to the development of these infections (Muller et al. 2005, Snak et al. 2014).

Zoos and other similar locations usually maintain wild animals in shelters surrounded by trees. This layout is proper for lowering stress levels, though it might limit the correct hygiene and disinfection of the enclosures. (Muller et al. 2005). Parasitic infections in captive animals are mainly linked to nutritional status, enclosure management, prophylactic procedures, and previously scheduled treatments. According to the International Union for Conservation of Nature (IUCN), the parasitic fauna identification is mandatory for clinical routine in wild animals, and reintroduction protocols (Freitas et al. 2001). According to Catão-Dias (2003), parasitic infections are one of the main diseases affecting wild animals, but the morbidity and mortality may be related to parasite species, parasitic load, as well as nutritional status and physiological conditions of the host.

Captive animals are susceptible to a wide variety of parasites. To support their development and well-being, control of parasitic diseases is necessary. Also, the knowledge about parasitic diseases is still considered unsatisfactory, although the number of researches in this field has increased over the last years (Soares et al. 2000). The objective of this study was to evaluate the parasitic infection in captive birds, mammals, and reptiles from the "Universidade de Caxias do Sul" (UCS) Zoo, located at Rio Grande do Sul state, Brazil, as well as rescued animals submitted to treatment in the same period.

\section{MATERIALS AND METHODS}

The total population studied was 76 animals. Out of the total, 72 belonged to the group, two were free-living, and two were captured and arrived during the evaluation period. Fifty percent (38/76) were birds, $35.53 \%$ (27/76) mammals, and $14.47 \%$ (11/76) reptiles, divided in 33 different enclosures at the UCS Zoo (Table 1). This

Table 1. Animal and enclosure identification from where stool samples were collected

\begin{tabular}{|c|c|c|}
\hline Enclosure & Scientific name & Number of animals \\
\hline 1 & Alouatta guariba clamitans & 5 \\
\hline 2 & Callithrix penicillata & 2 \\
\hline 3 & Nasua nasua & 2 \\
\hline 4 & Callithrix penicillata & 2 \\
\hline 5 & Leopardus tigrinus & 2 \\
\hline 6 & Cerdocyon thous & 1 \\
\hline 7 & Procyon cancrivorous & 1 \\
\hline 8 & Cebus apella & 2 \\
\hline 9 & Cebus apella & 3 \\
\hline 10 & Leopardus wiedii & 1 \\
\hline 11 & Puma concolor & 1 \\
\hline 12 & Leopardus pardalis & 1 \\
\hline 13 & Mazama gouazoupira & 2 \\
\hline 14 & Didelphis albiventris & 1 \\
\hline 15 & Cerdocyon thous & 1 \\
\hline 16 & $\begin{array}{l}\text { Atene cunicularia } \\
\text { Milvago chimachima }\end{array}$ & $\begin{array}{l}1 \\
1\end{array}$ \\
\hline 17 & Asio clamator & 1 \\
\hline 18 & Cyanocorax caeruleus & 1 \\
\hline 19 & Rupornis magnirostris & 2 \\
\hline 20 & Caracara plancus & 2 \\
\hline 21 & Ramphastos dicolorus & 2 \\
\hline 22 & $\begin{array}{l}\text { Cygnus atratus } \\
\text { Anser anser } \\
\text { Anas platyrhinchos domesticus }\end{array}$ & $\begin{array}{l}1 \\
1 \\
1\end{array}$ \\
\hline 23 & $\begin{array}{l}\text { Aratinga auricapillus } \\
\text { Aratinga sp. } \\
\text { Ara chloroptera }\end{array}$ & $\begin{array}{l}1 \\
2 \\
1\end{array}$ \\
\hline 24 & $\begin{array}{l}\text { Amazona amazônica } \\
\text { Amazona aestiva }\end{array}$ & $\begin{array}{c}1 \\
10\end{array}$ \\
\hline 25 & $\begin{array}{l}\text { Ara ararauna } \\
\text { Ara chloroptera } \\
\text { Ara macao }\end{array}$ & $\begin{array}{l}2 \\
1 \\
2\end{array}$ \\
\hline 26 & Rhea americana & 2 \\
\hline 27 & Amazona vinacea & 1 \\
\hline 28 & Amazona aestiva & 1 \\
\hline 29 & Pionus & 1 \\
\hline 30 & $\begin{array}{l}\text { Chelonoides carbonaria } \\
\text { Chelonoides denticulata }\end{array}$ & $\begin{array}{l}4 \\
1\end{array}$ \\
\hline 31 & Bothrops alternatus & 3 \\
\hline 32 & Crotulus durissus & 2 \\
\hline 33 & Bothrops cotiara & 1 \\
\hline Total & & 76 \\
\hline
\end{tabular}


study was evaluated and approved by the Committee on Animal Research and Ethics from UCS (CEUA-UCS), number 016/2018.

The material analyzed was collected from the enclosures in triplicate. The samples were collected on average of 5 enclosures per week, during alternate days, from September 2 nd to October 10 th, 2019. Only one sample was collected from the enclosure number 15 because the animal Cerdocyon thous died. Also, only one sample was collected from the enclosures 31,32, and 33, due to particular physiological differences in snakes. Therefore, 91 samples were analyzed in total. While collecting the samples, our team intended to collect fresh feces in the uppermost portion of the mound, seeking to reduce environmental contamination.

The samples were placed in properly identified plastic containers, transported in isothermal boxes to the "Laboratório de Parasitologia" of UCS, and analyzed within a maximum of 24 hours. Those samples that could not be analyzed immediately after collection were refrigerated until processed. The centrifugal-flotation technique with a zinc sulfate solution was chosen for the analyses, according to described by Faust et al. (1938). The identification of parasitic forms followed the morphological description of Zajac \& Conboy (2012), Urquhart et al. (2008), Lasprilla et al. (2009) and Monteiro (2017).

\section{RESULTS}

From a total of 91 samples analyzed, 43 (47.25\%) were from mammals, 42 (46.15\%) from birds, and 6 (6.6\%) from reptiles. Results showed 38 (41,76\%) positive samples for nematodes and/or cestodes and/or protozoa. From the positive samples, 21 (55.26\%) were birds from orders Falconiformes, Strigiformes, Piciformes, Anseriformes, Rheiformes, and Psittaciformes, 15 (39.47\%) mammals, orders Primate, Carnivora and Didelphimorphia, and 2 (5.27\%) reptiles, order Squamata (Table 2).

The positive samples were collected from 23 enclosures, three of which were evaluated once, and 20 were evaluated on alternate days in triplicate. From the last 20 samples, six enclosures were positive throughout the three collections,

Table 2. Positive samples prevalence for gastrointestinal parasites in mammals, birds, and reptiles at the "Zoológico da Universidade de Caxias do Sul", from September to October 2019

\begin{tabular}{lccc}
\hline \multicolumn{1}{c}{ Animal (Class, Order) } & $\mathrm{N}$ & $\mathrm{P}$ & $\%$ \\
\hline Aves, Falconiformes & 6 & 4 & 66.67 \\
Aves, Strigiformes & 3 & 1 & 33.33 \\
Aves, Passeriformes & 3 & 0 & 0.00 \\
Aves, Accipitriformes & 3 & 0 & 0.00 \\
Aves, Piciformes & 3 & 3 & 100 \\
Aves, Anseriformes & 3 & 1 & 33.33 \\
Aves, Rheiformes & 3 & 1 & 33.33 \\
Aves, Psittaciformes & 18 & 11 & 61.11 \\
Mammalia, Primate & 15 & 7 & 46.67 \\
Mammalia, Carnivora & 22 & 5 & 22.73 \\
Mammalia, Artiodactyla & 3 & 0 & 0.00 \\
Mammalia, & 3 & 3 & 100 \\
Didelphimorphia & & & \\
Reptile, Squamata & 3 & 2 & 66.67 \\
Reptile, Testudinata & 3 & 38 & 0.00 \\
TOTAL & 91 & & 41.76 \\
\hline
\end{tabular}

$\mathrm{N}=$ Number of collected samples, $\mathrm{P}=$ number of positive samples, $\%=$ prevalence. three were positive for at least two collections, and 11 were positive for only one collection. The presence of one or more parasites was detected. Parasites observed were from the orders Strongylida (34.21\%), Enoplida and Strongylida (23.68\%), only Enoplida (23.68\%), Cyclophyllidea and Oxyurida (5.26\%), Ascaridida only (5.26\%), Enoplida, Strongylida and Ascaridida (5.26\%), and Enoplida and Eucoccidiorida (2.63\%) (Table 3).

In mammal samples, oocysts of Eimeria sp., parasitic proglottids of the Class Cestoda, eggs of Trypanoxyuris sp., parasitic eggs from orders Enoplida, Ascaridida, and Strongylida were identified; the proglottids (Fig.1) present in the feces samples were fragmented and eggs of the Anoplocephalidae family (Fig.2) suggestive of Bertiella sp. were identifie. In bird samples, Capillaria sp. (Fig.3), parasites of the orders Enoplida, Strongylida (Fig.4), and Ascaridida were observed. In reptile samples, parasites of the order Strongylida and Ascaridida were found.

According to the Doctor in Veterinary Medicine responsible for the Zoo, the Leopardus tigrinus was the only animal throughout the zoo receiving oral antiparasitic treatment with pyrantel pamoate and oxantel pamoate, a month before the beginning of this study. It was also reported that some bird enclosures suffered a rodent invasion, more specifically enclosures with Aratinga auricapillus, Aratinga sp., Ara chloroptera; Amazona amazonica, Amazona aestiva; Ara ararauna, Ara chloroptera, and Ara macao. Additionally, during the collection period, some animals were quarantined, including an Amazona vinacea and a Pionus, that were rescued from illegal captivity. Furthermore, an $A$. aestiva was being treated due to its advanced age and nutritional status.

\section{DISCUSSION}

This study was carried out with parasitological exams of stool samples collected from the enclosures, without any physical contact with the animals. Therefore, there was no environmental interference or change in animal behavior throughout the study. The copro-parasitological sample exam is an effective and non-invasive method used to search for eggs, oocysts, and larvae of parasites in wild animals. However, according to Stuart et al. (1998), this exam has certain limitations such as not finding the adult form of parasites, which interferes with their complete taxonomic identification. In this study, many structures were identified only according to the parasite order, and some according to the genus. Another important factor to highlight was the evaluation in triplicate, since out of 20 positive samples, 11 samples were observed in only one analysis of the triplicate.

Parasites can act as primary disease agents or as opportunists, so they are considered a threat to the health of captive animals (Daszak et al. 2000, Freitas et al. 2001, Catão-Dias 2003). Most of the identified parasites have a monoxenous life cycle, making their transmission to the host easier (Freitas et al. 2002, Urquhart et al. 2008). The identified parasites that have a heteroxenous life cycle need an intermediate host (usually invertebrates) for transmission to occur (Urquhart et al. 2008). An example of an heteroxenous parasite is the genus Bertiella, identified in this study as a parasite of the species Alouatta guariba clamitans. This parasite has the oribatid mites as its intermediate host, which are arthropods commonly found in leaves that are served as food for animals (Dunn 1963). 
The results of the present study showed a high prevalence of parasites in the birds studied (50\%) since 21 samples were positive, out of 42 samples analyzed. Although mammals had a parasitism prevalence of $34.88 \%(15 / 43)$, they had the greatest parasitic diversity. Reptiles had a prevalence of $33.33 \%(2 / 6)$. Free-living animals are challenged by numerous infection sources, while animals in captivity have limited infection sources, which reduces the likelihood of a wide variety of parasite species (Freitas et al. 2001, SibajaMorales et al. 2009, Santos et al. 2011). However, according to Orsini \& Bondan (2006), animals in captivity are subjected to continuous stressful situations, triggering immunological disorders that can result in altering the resistance against parasitic infections.

The literature describes nematodes as the most common helminths in primates of the genus Alouatta, followed by cestodes and trematodes (Diniz 1997, Stuart et al. 1998), which is in agreement with our study because eggs of the nematode Trypanoxyuris sp. and proglottids of cestode Bertiella sp. were found in stool samples from A. guariba clamitans. Eating habits and their highly sociable behavior with close contact between these specie individuals may be associated with this parasitism. According to the studies carried out by Martins et al. (1997), howler monkeys tend to adopt defecation sites, giving preference to branches arranged both horizontally and inclined, therefore, the continuous use and reuse of the area are capable of making the environment contaminated by parasitic eggs and larvae. This habit facilitates reinfection by Trypanoxyuris sp., which has a direct life cycle. In consequence, environmental contamination occurs through feces and subsequent development of infectious form (Stuart et al. 1998).

A study by Souza-Junior (2007) investigated the parasitic fauna of A. guariba clamitans received and maintained at the Biological Research Center in Indaial, Rio de Janeiro state, from April 2005 to April 2006. Out of 28 animals monitored, Bertiella mucronata gravid proglottids were observed in at least one fecal sample in $50 \%$ of the animals. In this study, the presence of Bertiella sp. was verified in two of the three samples analyzed from the animals. It is important to mention that infection by Bertiella sp. is a zoonosis and has been reported in humans who have some contact or association with primates (Servián et al. 2020).

Table 3. Gastrointestinal parasites identified in samples of mammals, birds, and reptiles from the "Zoológico da Universidade de Caxias do Sul"

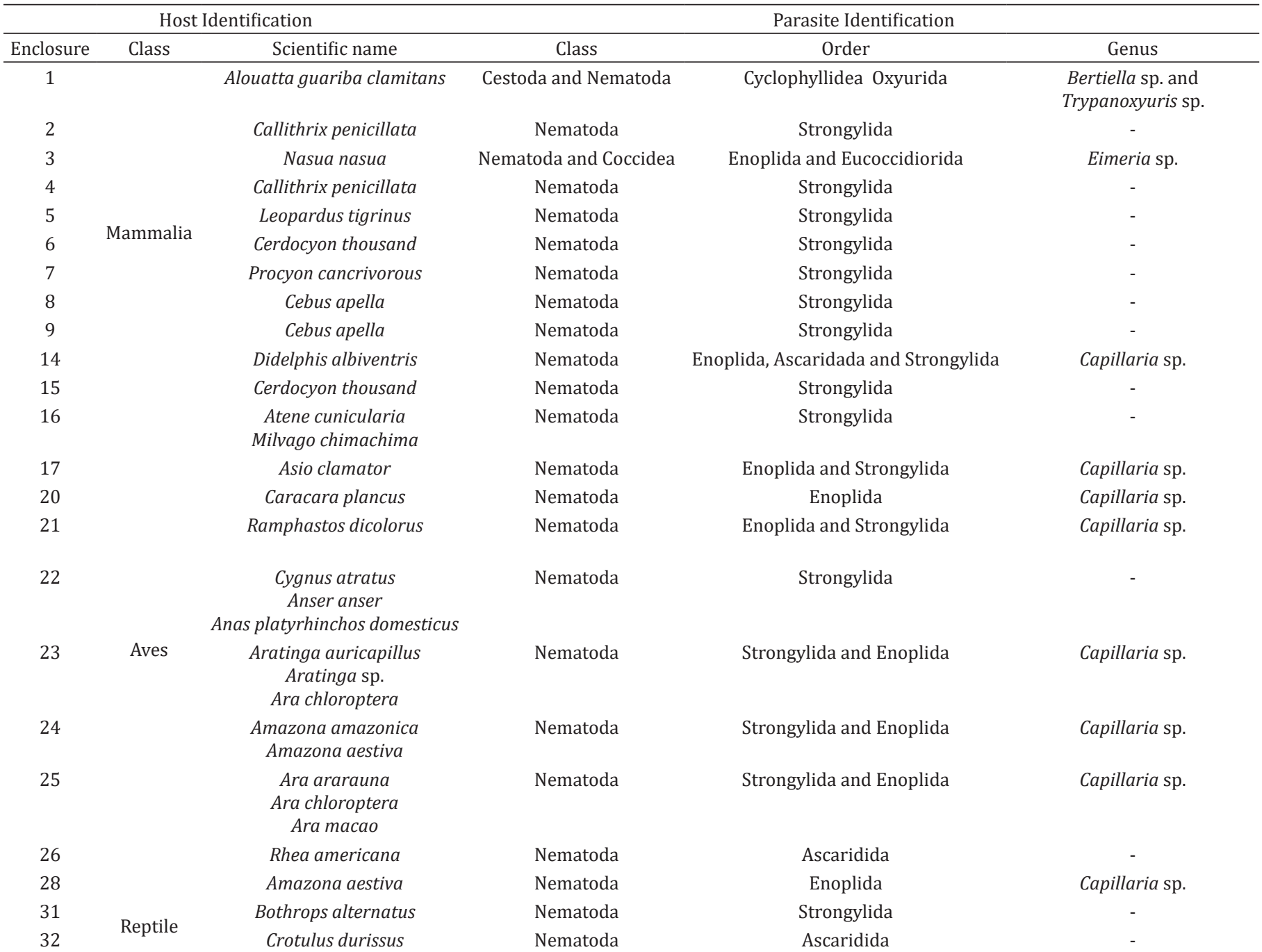


In stool samples of Cebus apella and Callithrix penicillata, the study identified the presence of parasites of the order Strongylida. According to Phillips et al. (2004) and Chinchilla et al. (2010) studies on parasitism in capuchin monkeys are limited. However, it is known that studies carried out in Peru and Costa Rica have identified the presence of parasites such as Strongyloides sp. and Ascaris sp. The parasitological survey carried out by Snak et al. (2017), from August 2010 to June 2012 at Parque Municipal Danilo Galafassi (Cascavel Zoo, Paraná state, Brazil), observed stool samples from 27 Cebus sp. and four Callithrix sp. which were positive for Strongyloides sp., Cystoisospora sp., parasites of the superfamily Strongyloidea, and eggs of Taenia spp. The results presented by the authors differ in parts from our results since they report only the presence of parasites of the order Strongylida, which can be explained by the limited sources of infections within the enclosures.

In the carnivores, the higher prevalence of parasites was those from the order Strongylida, in the samples of Leopardus tigrinus, Procyon cancrivorous, and Cerdocyon thous. In a

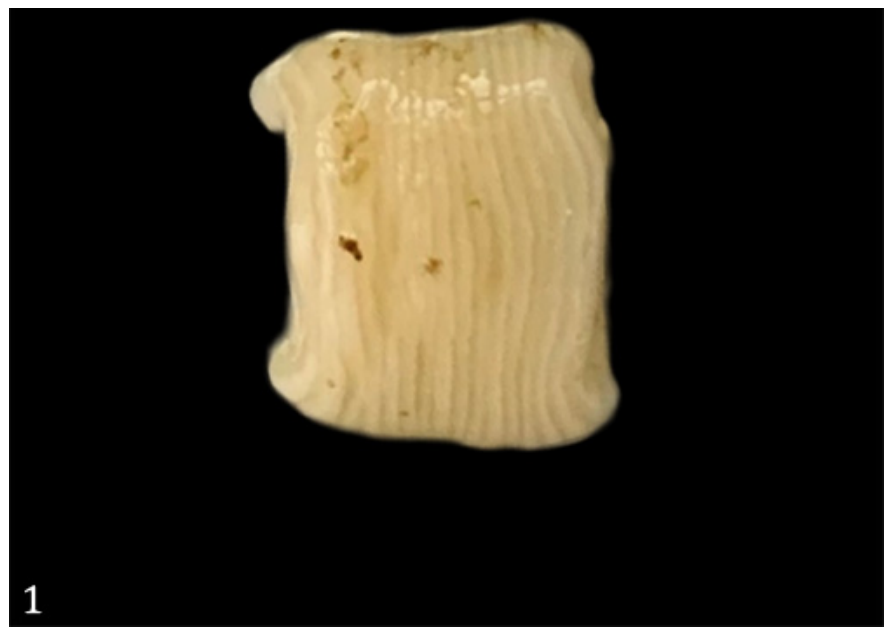

Fig.1. Parasitic proglottids of the class Cestoda present in feces samples of Alouatta guariba clamitans from the "Universidade de Caxias do Sul" Zoo.

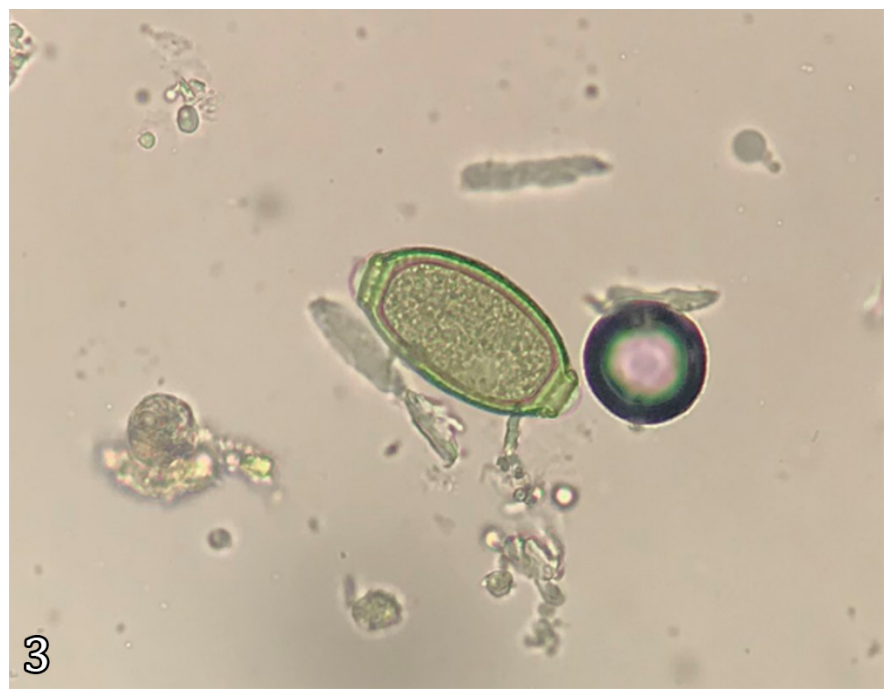

Fig.3. Egg of Capillaria sp. present in feces samples of birds from the "Universidade de Caxias do Sul" Zoo. study by Barros et al. (2017), it was observed parasites from the superfamily Strongyloidea in Leopardus tigrinus. In another study, Silva et al. (2016) identified Ancylostoma sp. in stool samples from P. cancrivorus. Ruas et al. (2008) reported the presence of helminths Ancylostoma caninum and Molineus felineus in C. thous. These results were similar to these animal species in this study, since superfamily, genera, and species of parasites mentioned belong to the order Strongylida. The samples from carnivores were also positive for the order Enoplida and the protozoa Eimeria sp., identified in the Nasua nasua. Soares (2012) identified specimens and eggs of Trichuris sp. in the jejunum, ileum, and colon regions of $N$. nasua. This result obtained by the previous author is in agreement with the findings in our study, however, the animal in our study was also positive for Eimeria sp.

The animal Didelphis albiventris was rescued by responsible entities and sent to the UCS zoo for further care. Upon fecal examination, the results were positive for parasites from

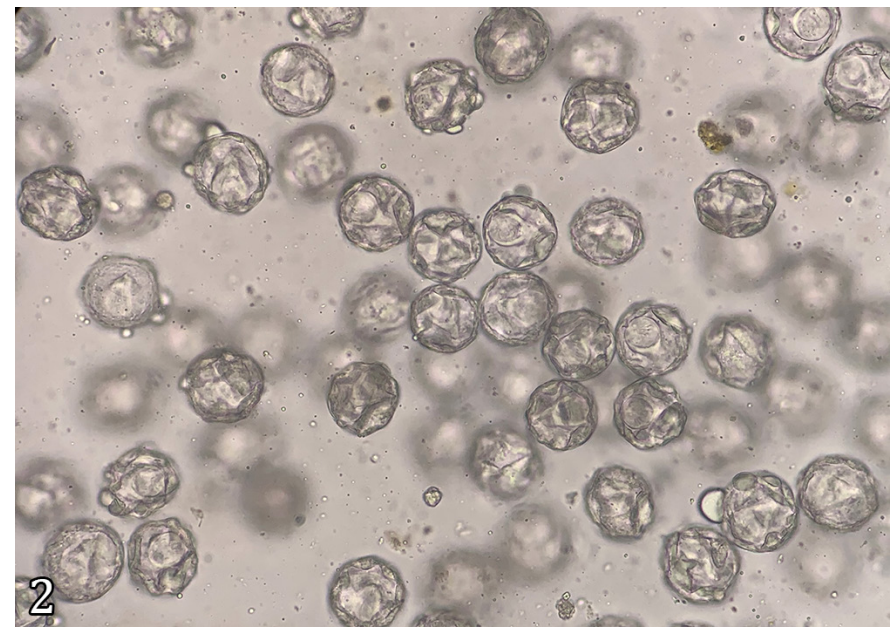

Fig.2. Eggs of the family Anoplocephalidae suggestive of Bertiella sp. from proglottids present in feces samples of Alouatta guariba clamitans from the "Universidade de Caxias do Sul" Zoo.

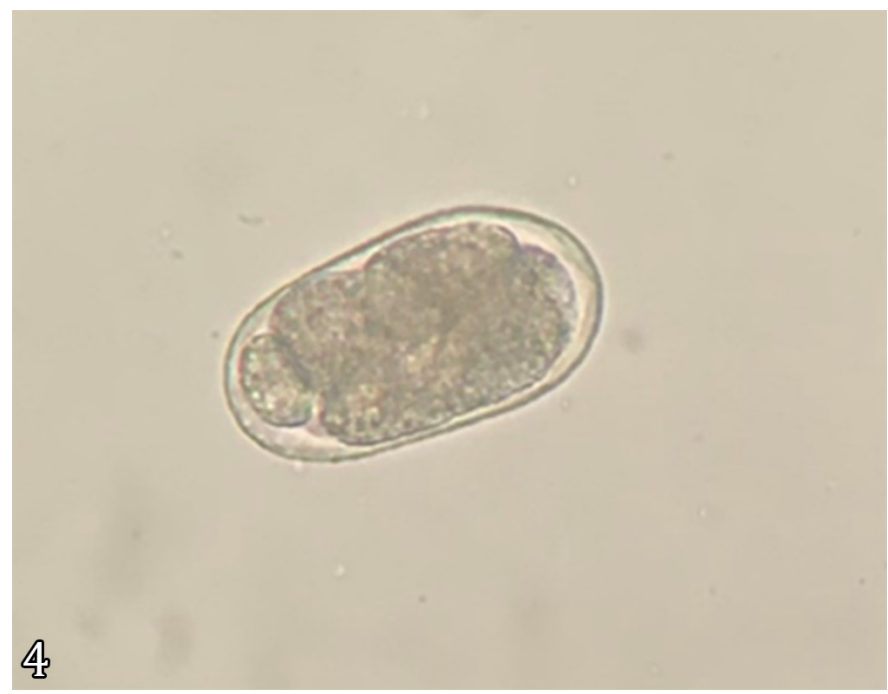

Fig.4. Egg of order Strongylida present in feces samples of birds from the "Universidade de Caxias do Sul" Zoo. 
order Enoplida, suspecting Capillaria sp., order Ascaridida, and order Strongylida. These results were similar to those found by Antunes (2005) who performed necropsy in 30 D. albiventris, which were positive for parasites from order Enoplida: Capillaria sp., Trichuris minuta, Trichuris didelphis; order Ascaridida: Aspidodera raillieti and Cruzia tentaculata; order Stronglylida: Viannaia hamata, Travassostrongylus orloffi, Didelphostrongylus hayesi, besides other parasites as Turgida turgida and Gnathostoma sp. The diversity of parasite eggs found in the referenced study might be explained by the $D$. albiventris omnivorous eating habits, and for being a free-living animal, having constant contact with different sources of infection.

Among the helminths identified in birds, Capillaria sp. and parasites from the order Strongylida were the most frequent in the stool samples of Strigiformes: Asio clamator; Falconiformes: Caracara plancus; Piciformes: Ramphastos dicolorus; Psittaciformes: Aratinga auricapillus, Aratinga sp., Amazona amazonica, Amazona aestiva, Ara chloroptera, Ara ararauna, and Ara macao. These birds were positive for at least one of the parasites mentioned. Eggs from order Ascaridida were identified in Rheiformes: Rhea americana. Eggs from order Strongylida were identified in Falconiformes Milvago chimachim and Anseriformes Cygnus atratus, Anser anser, and Anas platyrhinchos domesticus. At the city Santa Maria, Rio Grande do Sul state, Brazil, Da Silva et al. (2009) observed the presence of Capillaria sp., Strongylida parasites, and coccidia in fecal samples of Strigiformes kept in captivity, which is a similar result found in the current study, even though Coccidia was not seen in our samples from birds.

Santos et al. (2015) reported the presence of Capillaria sp. eggs and Eimeria sp. in Psittaciformes stool samples, and only Eimeria sp. in Falconiformes stool samples. These findings are different than our study, provided that this study found Capillaria sp. eggs and eggs from Strongylida order, in at least one group of these birds. Oliveira et al. (2016) identified eggs from Capillaria sp., in Falconiformes Carcara plancus, and the results of the present study are well-matched with the author's findings. Gallo (2013) observed eggs from Baylisascaris sp. in Rhea americana, similar to the findings in the current study since the parasite identified by the author belongs to the order Ascaridida. As previously mentioned, some bird enclosures suffered a rodent invasion, which may influence the diversity of parasites found in this group. Besides, factors such as stress, free-living birds accessing the enclosures, contaminated soil, and ingestion of earthworms, which are intermediate or paratenic hosts, may be associated.

Among the reptiles, according to the results, only the snakes were parasitized, and out of the 3 samples analyzed from these animals, two were positive, with a prevalence of $66.67 \%$. Out of the species analyzed, Bothrops alternatus were positive for larvae from order Strongylida, Crotulus durissus was positive for eggs from order Ascaridida, and Bothrops cotiara was negative. These results were similar to those found by Souza et al. (2014), who analyzed snakes stool samples from the "Instituto Vital Brasil", in Rio de Janeiro state, and obtained prevalence of Kalicephalus sp. (25\%), eggs from Ascaridae family (14.3\%), eggs from superfamily Rhabditoidea (8.9\%), and presence of nematode larvae. Schad (1956) speculated the occurring infection of these animals through the habit of recognizing their environment through the tongue, providing the oral infection. Other factors related to snake parasitism might be contaminated food and water, or inefficient deworming before introducing to the enclosures.

\section{CONCLUSIONS}

The identification of parasites in captive animals is extremely important for the elaboration of an appropriate deworming protocol for each studied group. We observed that Strongylida parasites were the most prevalent, with mono-infection in $34.21 \%$ of the analyzed samples and mixed infection in 28.94\%. The order Enoplida was positive in 55.25\% of samples, standing out as the second most prevalent order in the study, affecting mainly birds.

Another relevant factor was that animal classes showing the highest prevalence of positive samples were birds and mammals, requiring greater attention.

The results obtained show the importance of the triplicate sample evaluation, since out of the 20 enclosures evaluated in triplicate, 11 were positive in only one of the evaluations.

Conflict of interest statement.- The authors have no competing interests.

\section{REFERENCES}

Antunes G.M. 2005. Diversidade e potencial zoonótico de parasitas de Didelphis albiventris Lund, 1841 (Marsupialia: Didelphidae). Doctoral Dissertation, Universidade Federal do Rio Grande do Sul, Porto Alegre. 122p.

Barros L.A., Sant'Anna L.X. \& Magalhães B.S. 2017. Prevalência de parasitos gastrointestinais em mamíferos selvagens do Jardim Zoológico do Rio de Janeiro. Revta Bras. Ciênc. Vet. 24(4):179-183. <https://dx.doi.org/10.4322/ rbcv.2017.034>

Birchard S.J. \& Sherding R.G. 1998. Manual Saunders: clínica de pequenos animais. Roca, São Paulo. 2072p.

Catão-Dias J.L. 2003. Doenças e seus impactos sobre a biodiversidade. Ciênc. Cult. 55(3):32-34.

Chinchilla M., Urbani B., Valerio I. \& Vanegas J.C. 2010. Parasitosis intestinal en monos capuchinos cariblancos Cebus capucinus(Primates: Cebidae) de un área protegida en la provincia de Limón, noreste de Costa Rica. Revta Biol. Trop. 58(4):1335-1346. <https://dx.doi.org/10.15517/RBT.V58I4.5416>

Da Silva A.S., Zanette R.A., Lara V.M., Gressler L.T., Carregaro A.B., Santurio J.M. \& Monteiro S.G. 2009. Gastrointestinal parasites of owls (Strigiformes) kept in captivity in the Southern region of Brazil. Parasitol. Res. 104(2):485-487. <https://dx.doi.org/10.1007/s00436-008-1257-0> <PMid:19005679>

Daszak P., Cunningham A.A. \& Hyatt A.D. 2000. Emerging infectious diseases of wildlife: threats to biodiversity and human health. Science 287(5452):443449. <https://dx.doi.org/10.1126/science.287.5452.443><PMid:10642539>

Diniz L.S.M. 1997 Primatas em Cativeiro: manejo e problemas veterinários. Editora Ícone, São Paulo. 195p.

Dunn F.L. 1963. Acanthocephalans and Cestodes of South American monkeys and marmosets. J. Parasitol. 49(5):717-722. <https://dx.doi. org/10.2307/3275912><PMid:14070470>

Faust E.C., D’Antoni J.S., Odom V., Miller M.J., Peres C., Sawitz W., Thomen L.F., Tobie J. \& Walker J.H. 1938. A critical study of clinical laboratory technics for the diagnosis of protozoan cysts and helminth eggs in feces. Preliminary communication. Am. J. Trop. Med. s1-18(2):169-183. <https://dx.doi. org/10.4269/ajtmh.1938.s1-18.169>

Freitas M.F.L., Oliveira J.B., Cavalcanti M.D.B., Leite A.S., Magalhães V.S., Oliveira R.A. \& Evencio-Sobrinho A. 2002. Parásitos gastrointestinales aves silvestres en cautiverio en el estado de Pernambuco, Brasil. Parasitol Latinoam 57 (12):50-54. <https://dx.doi.org/10.4067/S0717-77122002000100012> 
Freitas M.F.L., Oliveira J.B., Cavalcanti M.D.B., Oliveira R.A. \& Evencio-Sobrinho A. 2001. Perfil coproparasitológico de mamíferos silvestres en cautiverio en el Estado de Pernambuco, Brasil. Parasitología al Día 25(3-4):121-125. <https://dx.doi.org/10.4067/S0716-07202001000300009>

Gallo S.S.M. 2013. Parasitas gastrintestinais em emas, Rhea americana, de um Criatório científico em Campos dos Goytacazes - RJ: aspectos morfológicos e moleculares. Master's Thesis, Universidade Estadual do Norte Fluminense Darcy Ribeiro, Rio de Janeiro, RJ. 105p. Available at <http://uenf.br/ posgraduacao/ciencia-animal/wp-content/uploads/sites/5/2013/08/ disserta\%C3\%A7\%C3\%A3o-Samira-Gallo.pdf> Accessed on Feb. 12, 2021.

Lasprilla M., Ocampo M. \& López G. 2009. Identificación de huevos de nemátodos en carnívoros y primates ubicados en el Zoológico Santa Fe de Medellín, mediante método coprológico directo y de flotación. Revta Spei Domus 5(10):30-36.

Martins S.S., Limeira V.L.A.G. \& Rodrigues M.L.A. 1997. Comportamento de defecação e ocorrência de endoparasitas nas amostras fecais de Alouatta fusca num fragmento de mata semidecídua no Estado do Rio de Janeiro. VIII Congresso e V Reunião Latino-Americana de Primatologia, João Pessoa, PB, p.109.

Monteiro S.G. 2017. Parasitologia na Medicina Veterinária. 2aa ed. Roca, Rio de Janeiro. 370p.

Muller G.C.K., Greinert J.A. \& Silva Filho H.H. 2005. Frequência de parasitas intestinais em felinos mantidos em zoológicos. Arq. Bras. Med. Vet. Zootec. 57(4):559-561. <https://dx.doi.org/10.1590/S0102-09352005000400021>

Oliveira V.J., Teixeira R.E.R., Santos C.M.R., Santana I.S.F., Santos N.F., Macedo E.C., Silva M.B., Rocha A.A. \& Fraga R.E. 2016. Avaliação de parasitas gastrointestinais de avifauna silvestre mantidas em Vitória da Conquista, Bahia. Undergraduate Thesis, Universidade Federal da Bahia, Salvador, BA. Available at <http://repositorio.ufba.br/ri/handle/ri/19235> Accessed on Feb. 25, 2021.

Orsini H. \& Bondan E.F. 2006. Fisiopatologia do estresse em animais selvagens em cativeiro e suas implicações no comportamento e bem-estar animal revisão da literatura. Revta Inst. Ciênc. Saúde 24(1):7-13.

Phillips K., Haas M., Grafton B. \& Yrivarren M. 2004. Survey of the gastrointestinal parasites of the primate community at Tambopata National Reserve, Peru. J. Zool. 264(2):149-151.<https://dx.doi.org/10.1017/S0952836904005680>

Ruas J.L., Muller G., Farias N.A.R., Gallina T., Lucas A.S., Pappen F.G., Sinkoc A.L. \& Brum J.G.W. 2008. Helmintos do cachorro do campo, Pseudalopex gymnocercus (Fischer, 1814) e do cachorro do mato, Cerdocyon thous (Linnaeus, 1766) no sul do estado do Rio Grande do Sul, Brasil. Revta Bras. Parasitol. Vet. 17(2):87-92. <https://dx.doi.org/10.1590/S198429612008000200005>

Santos P.M.S., Silva S.G.N., Fonseca C.F. \& Oliveira J.B. 2015. Parasitos de aves e mamíferos silvestres em cativeiro no estado de Pernambuco. Pesq. Vet. Bras. 35(9):788-794. <https://dx.doi.org/10.1590/S0100-736X2015000900004>

Santos T., Oliveira J.B., Vaughan C. \& Santiago H. 2011. Health of an ex situ population of raptors (Falconiformes and Strigiformes) in Mexico: diagnosis of internal parasites. Revta Biol. Trop. 59(3):1265-1274.

Schad G. 1956. Studies os the genus Kalicephalus (nematoda diaphanocephalidae): I. On the life histories of the North American species K. Parvus, K. Agkistrodontis, and K. Rectiphilus. Can. J. Zool. 34(5):425-452. <https:// dx.doi.org/10.1139/z56-047>
Servián A., Zonta M.I., Cociancic P., Falcone A., Ruybal P., Capasso S. \& Navone G.T. 2020. Caracterização morfológica e molecular de Bertiella sp. (Cestoda Anoplocephalidae) em humanos e macacos bugios na Argentina. Parasitol. Res. 119(4):1291-1300.<https://dx.doi.org/10.1007/s00436-020-06615-5> <PMid:32025808>

Sibaja-Morales K.D., Oliveira J.B., Rocha A.E.J., Hernándes-Gamboa J., Prendas-Gamboa J., Arroyo-Murillo F., Sandí J., Nuñez Y. \& Baldi M. 2009. Gastrointestinal parasites and ectoparasites of Bradypus variegatus and Choloepus hoffmanni sloths in captivity from Costa Rica. J. Zoo Wildl. Med. 40(1):86-90. <https://dx.doi.org/10.1638/2008-0036.1><PMid:19368244>

Silva M.F., Gonçalves I.C.M., Gino A.M.O. \& Pereira S.M. 2016. Identificação de parasitos encontrados em animais de vida livre encaminhados a uma clínica veterinária particular - resultados preliminares. I Semana de Ensino, Pesquisa e Extensão, Intituto Federal Catarinense, Araquari, SC. 5p. Available at <http://eventos.ifc.edu.br/sepe/wp-content/uploads/sites/22/2016/08/ IDENTIFICA \%C3\%87\%C3\%830-DE-PARASITOS-ENCONTRADOSEM-ANIMAIS-SILVESTRES-DE-VIDA-LIVRE-ENCAMINHADOS-A-UMACL\%C3\%8DNICA-VETERIN\%C3\%81RIA-PARTICULAR-\%E2\%80\%93RESULTADOS-PRELIMINARES.pdf> Accessed on Mar. 4, 2021.

Snak A., Agostini K.M., Lenzi P.F., Montanucci C.R., Delgado L.E. \& Zabott M.V. 2017. Perfil parasitológico de mamíferos silvestres cativos. Vet. Zootec. 24(1):193-200

Snak A., Lenz P.F., Agostini K.M., Delgado L.E., Montanucci C.R. \& Zabott M.V. 2014. Análises coproparasitológicas de aves silvestres cativas. Ciênc. Anim. Bras. 15(4):502-507. <https://dx.doi.org/10.1590/1809-6891v15i425797>

Soares C.A., Oliveira J.B. \& Brito M.D.C. 2000. Infecção natural por Entamoeba histolytica Schaudinn, 1903 em Euphractus sexcinctus (tatu) mantida em cativeiro. Arq. Bras. Med. Vet. Zootec. 52(3):208-209. <https://dx.doi. org/10.1590/S0102-09352000000300004>

Soares R. 2012. Helmintofauna de Procyon cancrivorus (G. [Baron] Cuvier, 1798) Nasua nasua (Linnaeus, 1766) e Galictis cuja (Molina, 1782), atropelados na BR-116, Rio de Janeiro, Teresópolis, Além Paraíba, RJ, Brasil. Master's Thesis, Universidade Federal Fluminense, Niterói, RJ. 154p. Available at <https://app.uff.br/riuff/handle/1/6644> Accessed on Feb. 7, 2021.

Souza J.L., Barbosa A.S., Vazon A.P., Uchôa C.M.A., Nunes B.C., Cortez M.B.V., Silva V.L., Más L.B., Melgarejo A.R. \& Bastos O.M.P. 2014. Parasitological and immunological diagnoses from feces of captive-bred snakes at Vital Brazil Institute. Revta Bras. Parasitol. Vet. 23(2):123-128. <https://dx.doi. org/10.1590/S1984-29612014032><PMid:25054488>

Souza-Junior J.C. 2007. Perfil sanitário de bugios ruivos, Alouatta guaribaclamitans (Cabrera, 1940) (Primates: Atelidae): um estudo com animais recepcionados e mantidos em perímetro urbano no município de Indaial, Santa Catarina - Brasil. Master's Thesis, Graduate Program in Public Health, Universidade Federal de Santa Catarina, Florianópolis, SC. 111p. Available at <https://core.ac.uk/download/pdf/30371072.pdf> Accessed on Feb. 10, 2021.

Stuart M., Pendergast V., Rumfelt S., Pierberg S., Greenspan L., Glander K. \& Clarke M. 1998. Parasites of wild howlers (Alouatta spp.). Revta Int. Primatol. 19(3):493-512.

Urquhart G.M., Armour J., Duncan J.L., Dunn A.M. \& Jennings F.W. 2008 Veterinary Parasitology. 2nd ed. Blackwell, USA. 275p.

Zajac A.M. \& Conboy G.A. 2012. Veterinary Clinical Parasitology. 8th ed. Blackwell, USA. 368p. 